\title{
CHARITABLE GIFTS OF INCOME AND THE INTERNAL REVENUE CODE: ANOTHER VIEW
}

\author{
Boris I. Bittker *
}

TN the November, 195I, issue of this Review Dean Griswold 1 commented on two controversial recent rulings of the Treasury. ${ }^{1}$ His remarks were partly prompted by a criticism of these rulings by Mr. Robert N. Miller, whom Dean Griswold felicitously calls "the dean of the tax bar," in the Tax Law Review." May I take issue with both deans and toss a brickbat in passing at the Treasury?

The first ruling held that a farmer who made a gift of homegrown wheat to a charity could deduct its fair market value as a charitable contribution (subject to the usual fifteen percent limitation) but must also include that value in gross income. ${ }^{3}$ The farmer had deducted the cost of raising the wheat as a business expense and presumably had hoped to deduct its value as a charitable contribution. The Treasury allowed the two deductions, but, by requiring the value of the wheat to be included in gross income, it taxed the farmer as though he had sold the crop for cash and donated the proceeds to the charity.

The ruling purports to rest upon Helvering v. Horst, ${ }^{4}$ and $\mathrm{Mr}$. Miller strongly urges that its footing is weak. His criticism stems partly from his view that Horst is a "fruit and tree" 5 case - that

* Professor of Law, Yale Law School. B.A., Cornell, r938; LL.B., Yale, x94r.

${ }^{1}$ Griswold, Charitable Gifts of Income and the Internal Revenue Code, 65 HaRv. L. REv. 84 (I95I) (hereinafter Griswold). The author has also had the benefit of correspondence with Dean Griswold on this subject.

${ }^{2}$ Miller, Gifts of Income and of Property: What the Horst Case Decides, 5 TAX L. Rev. I (I949).

${ }^{3}$ I.T. 3910, I948-I CuM. BuLL. I5. The principle enunciated in the ruling was applied by a later ruling to a dealer's contribution of building materials to a civil defense organization. Special Ruling, 5 CCH 1952 FED. TAX REP. \ 6I25 (Oct. 8, I95I).

${ }_{3}^{4}$ II U.S. II2 (I940).

${ }^{5}$ Molloy, indeed, holds the Horst case liable for sowing "a lamentable host of horticultural metaphors." Molloy, Some Tax Aspects of Corporate Distributions in Kind, 6 TAX L. REv. 57, 6I (r950). In point of fact, Lucas v. Earl, 28I U.S. III (I930), is the culprit. 
the father by keeping the bond and giving his son only the interest coupons had retained

the sole source out of which this income flowed . . . . The same result would have been achieved in that case if the father had merely written a letter to the obligor constituting his son his nominee to receive payment of the interest and authorizing the son to keep the money instead of passing it back to his father, the bond owner. . . . The further running of interest in anyone's favor could, in fact, have been stopped at any time by the father's accepting payment of the principal from the obligor. ${ }^{6}$

In the case of the farmer, of course, the donee's control over the donated property is unqualified. The only trouble with Mr. Miller's theory is that it rests upon the incorrect assumption that the interest coupons in the Horst case had no "independent value" apart from the bond. In point of fact, the coupons were negotiable, and it was precisely for this reason that Chief Justice Hughes and Justices McReynolds and Roberts dissented in the Horst case and that Judge Patterson had held below that the donor was not taxable:

The petitioner could not interfere in any way with the donee's control and right to receive the money when the coupons matured. . . . Generally liability to income tax attaches to ownership of the income, Blair v. Commissioner, 300 U.S. 5 , and we see nothing to take the case out of the general rule. The case is not one where the assignor had power over the income after the assignment, as in Corliss v. Bowers, 281 U.S. $376 .^{7}$

The Horst case, then, cannot be limited, as Mr. Miller suggests, to situations wherein the donor retains a power to veto the donee's claim. This is made doubly clear by Helvering $v$. Eubank, ${ }^{8}$ decided the same day as the Horst case, where the Court held the assignor of a contract taxable on sums paid pursuant to it, though he had relinquished all rights under it. The court so decided "For the reasons stated at length in the opinion in the Horst case." 9

${ }^{6}$ Miller, supra note 2 , at 6.

${ }^{7}$ I07 F.2d 906, 907 (2d Cir. 1939).

8 3II U.S. I22 (I940).

"Id. at I25. The reasons so "stated at length" require a little trimming to fit the Eubank case. See Surrey, The Supreme Court and the Federal Income Tax: Some Implications of the Recent Decisions, 35 IrI. I. REv. 779, 789-90 (I94I). Judge Wyzanski's recent description of the Massachusetts Supreme Judicial Court is apposite here, if seldom elsewhere in the United States Supreme Court's recent work: "Subtle variations and blurred lines are not characteristic of that 
Mr. Miller's criticism of the ruling also rests upon the fact that it treats the gift itself as a realization of income, whereas the Horst case treats the donee's receipt of the funds as the taxable event. If this were the ruling's only departure from the Horst case, the Treasury could of course easily meet Mr. Miller's objection without aiding the farmer. The only change required would be to tax the farmer on the fair market value of the crop when it is either sold or otherwise disposed of by the charity. ${ }^{10}$

To my mind, it is profitless in judging the Treasury ruling to seize upon this phrase or that detail of the Horst case. There are both similarities and differences; room for the ruling might be found at the Horst case's ample bosom, or it might be turned away. The arguments have been well canvassed elsewhere, ${ }^{11}$ and they are less than conclusive.

Whatever the courts may ultimately say of the ruling's validity, ${ }^{12}$ the Treasury has a responsibility for administering the tax laws in an intelligent manner. The legally permissible should be the only boundary no more in tax administration than in official morality. This responsibility for orderly administration seems to me to have been abdicated here. The ruling is superficially persuasive, in that it taxes a gift of the crop itself as though the crop had been sold and the proceeds donated to the charity; there is certainly a presumption in favor of treating functionally identical transactions the same regardless of differences in form. Yet in saying that these two transactions having the same nontax results shall be taxed the same, the Treasury treats the farmer differently from other philanthropic taxpayers, and it is for this reason that I think the ruling was inadvisable.

court. Principles are announced and adhered to in broad magisterial terms." Pomerantz v. Clark, IoI F. Supp. 34I, 346 (D. Mass. I95I).

${ }^{10}$ The wheat involved in the ruling itself was to be distributed by the charity.

${ }^{11}$ Note, Gratuitous Disposition of Property as Realization of Income, 62 HARv.

L. REv. II8I (I949); see the thoughtful comments of Surrey, supra note 9, at 784-92.

${ }^{12}$ In White v. Brodrick, 5 CCH I952 FED. TAX REP. I 9238 (D. Kan. March 6, I952), it was held that a farmer did not realize income by a charitable contribution of wheat, though his costs had been deducted. There was no opinion and the ruling was not mentioned. The farmer had not claimed the contribution as a charitable deduction, though his other contributions were less than $15 \%$ of his adjusted gross income. In a Special Ruling, 5 CCH I952 FED. TAX REp. If 6I25 (Oct. 8, I95I), the Bureau stated that the Tax Court in W. G. Farrier's Estate, 15 T.C. 277 (I950), reached a "contrary conclusion" to that of I.T. 39ro. But the Farrier case involved a gift to a noncharitable donee, so that there was no possibility of a double deduction. 
The trouble with the ruling, to my mind, is that the taxpayer who contributes appreciated securities to a charity may deduct their full fair market value without reporting his "unrealized" gain as income. $\mathrm{He}$ is not taxed as though he had sold the stock and then donated the proceeds to charity. Although this curious rule cannot be defended on logical grounds, ${ }^{13}$ both $\mathrm{Mr}$. Miller and Dean Griswold point out that Congress seems unwilling to change it ${ }^{14}$ and both quite rightly assume that the Treasury's ruling must be examined within this framework. ${ }^{15}$

Dean Griswold urges in support of the Treasury ruling that the farmer has "realized" his income when he harvests his wheat. Although, says Dean Griswold, for reasons of convenience "the tax law has long taken the obvious practical route" of allowing the farmer to postpone reporting the income until the crop is sold, "if the farmer frustrates the objective of the concession, by giving away the income already realized, it seems entirely appropriate to require the farmer to include in his return the amount of the in-

${ }^{13}$ Among other shortcomings it may penalize the taxpayer who is not properly guided for doing what comes naturally, since if he pledges a specific amount in a charitable drive he probably will realize income on satisfying the pledge with appreciated securities.

14 The "rule" rests upon U.S. Treas. Reg. III, $\$ 29.23(0)-I$ (I943). See Griswold at $9 \mathrm{r}$ n.20. In actuality this regulation merely allows fair market value to be deducted; it does not say that the gift itself is not a realization of that part of the value which equals the property's appreciation over its adjusted basis. But taxpayers and the Treasury have long acted as though this were the unstated consequence of the regulation. A proposed statutory change (limiting the deduction to cost) was rejected in 1938 . Griswold at 92 n.2x. It is now unlikely that the Treasury would attempt either to tax the gift as a realization or to amend the regulation so as to limit the deduction to cost. This is true despite the fact that much of what Mr. Justice Stone wrote in the Horst case fits the charitable gift of appreciated securities like a glove:

The taxpayer has equally enjoyed the fruits of his labor or investment and obtained the satisfaction of his desires whether he collects and uses the income to procure those satisfactions, or whether he disposes of his right to collect it as the means of procuring them. ... Such a use of his economic gain, the right to receive income, to procure a satisfaction which can be obtained only by the expenditure of money or property, would seem to be the enjoyment of the income whether the satisfaction is the purchase of goods at the corner grocery, the payment of his debt there, or such non-material satisfactions as may result from the payment of a campaign or community chest contribution, or a gift to his favorite son. 3II U.S. at II $\%$.

${ }^{15}$ To be sure, the donor of appreciated securities ordinarily avoids only a capital gain, whereas the donor of farm products would, in the absence of the ruling, ordinarily avoid the reporting of ordinary income. It would be hazardous, however, to conclude that the average farmer's tax rate on ordinary income is greater than the rate that the average investor would pay on his securities profits. Moreover, there is nothing in the history of the rule on charitable gifts, let alone in the Horst case, to suggest that a gift should be treated as a realization of ordinary income but not of capital gain. 
come which he has already realized, even though he has not converted it into cash." 16 Given the regulation exempting the appreciation on donated securities, ${ }^{17} \mathrm{I}$ cannot agree. The value of an agricultural crop at the time of its harvest seems to me no more significant than the value of an investor's property at year's end or at any other time prior to its sale or other disposition. Unrealized appreciation or depreciation is treated as inconsequential in the investor's case because the property is still at the mercy of the market; ${ }^{18}$ so too the value of the farmer's wheat is still dependent upon the fluctuations of the market. ${ }^{19}$ Neither taxpayer has yet enjoyed more than a paper profit. ${ }^{20}$ This is not to say that a sale for cash is essential to recognition of income; of course it is not. If either the investor or the farmer traded his property for shoes or ships or sealing wax he would clearly have a profit that

${ }^{16}$ Griswold at 87 . The value at the time of gift may be very different from the value at the time of harvesting. Dean Griswold's rationale for the Treasury ruling would require reporting the latter value, though the ruling itself apparently takes the value at the time of gift as crucial.

${ }^{17}$ See note $\mathrm{r}_{4}$ supra. The regulation speaks only of a contribution "other than money." In emphasizing its applicability to appreciated securities I am merely taking the most frequent example of its use. It may be noted that on its face the regulation is as applicable to agricultural products as to any other kind of property.

${ }^{18}$ Perhaps our tax system would be improved if such "unrealized" gain or loss had to be accrued; but the Code does not now impose such a requirement. Of course, as Dean Griswold points out, "income may be realized in a medium other than cash," Griswold at 87 ; familiar examples are compensation in kind under U.S. Treas. Reg. III, $\S 29.22$ (a)-3 (I943) and barters under INT. REv. CODE $\S \operatorname{III}(\mathrm{b})$. But in these cases there is a realization of income for all purposes: the taxpayer gets a basis for the property so that subsequent gains or losses are separately reckoned up, so that he may depreciate the property, so that he may take a casualty loss, and so forth. In the case of crops, as Dean Griswold recognizes, harvesting is not a realization of income for any of these purposes.

${ }^{19}$ The act of harvesting, it happens, is a physical severance. But though this means that one who wrongfully appropriates the grain is a thief rather than a trespasser and though it may be important in other branches of the law, I find no tax significance to it. The value of the crop varies constantly from the date the seed is sowed until the grain is sold; the date of harvest seems to me no more important for income tax purposes than the last day of the taxable year. That Dean Griswold is overemphasizing a neutral act - severance - is shown by his statement that his support of the ruling would fail if the farmer gave the standing crop to the charity, allowing the charity to make its own arrangements for harvesting the crop, Griswold at 88 n.I5. In these circumstances, presumably Dean Griswold would find no realization of income. Surely the timing of the gift should not be this important.

${ }^{20}$ If before sale the farmer gets a Government commodity loan without personal liability, something can be said for taxing him on the proceeds of the loan; to that extent, he is protected against future market fluctuations. See Lurie, Mortgagor's Gain on Mortgaging Property for More than Cost without Personal Liability, 6 TAX L. Rev. 3 I9 (I95I). But cf. Woodsam Associates, Inc., I6 T.C. 649 (I95I). 
would be - and ought to be - taxed. Nor am I making a constitutional objection to taxing the farmer when his crop is severed but before it is disposed of; I do not doubt that he could be taxed at that point. Despite Eisner v. Macomber, ${ }^{21} \mathrm{I}$ think all taxpayers could be put on an annual inventory basis with appreciation and depreciation being tallied up and taken into the tax return at year's end.

Thus, the farmer's wheat and the investor's appreciation seem to me to be comparable whether the issue is constitutional liability to tax or desirable tax policy. We do not say that an investor has received a "concession" in being allowed to postpone gain until the property has been sold or that he has "frustrated" the objective of that concession if he gives the property away. ${ }^{22}$ Neither, it seems to me, has the farmer. If the investor doesn't realize income when he gives appreciated property away, why should the farmer realize it when he harvests a crop that he subsequently gives away?

. Dean Griswold's answer to this question is that the farmer is giving away

what might be called an "income" item. It is an item produced in the course of trade or business, and which, upon sale, would be fully includible in gross income . . . .23

... The gift of appreciated property [for example, securities] is not the same as the gift of "income." There are similarities, but there is one important distinction. The gift of appreciated property does not involve any double deduction. ${ }^{24}$

21252 U.S. $x 89$ (I920).

${ }^{22}$ Dean Griswold uses $\S 44$ (d) as an analogy, Griswold at 87 n.I4; it provides that if a taxpayer elects to postpone gain represented by an installment obligation he must account for the gain thus postponed upon giving the obligation away by reporting the difference between its basis and its value. But here the taxpayer does have a closed transaction upon the sale of the property on an installment basis; postponement of his gain is a "concession" the purpose of which would be "frustrated" if he could give the obligation away with impunity. Section I26(a)(2), Dean Griswold's other analogy, is similarly limited to items that unquestionably constitute income, though because of the decedent's accounting method they have not yet been reported. An account receivable, for example, if unreported by the decedent because he was on a cash receipts and disbursements basis, must be reported by the estate when collected, when sold, or when given away. But items that are not realized income (for example, appreciated property) are not taxable under $\S I 26$ (a) (2) when given away. Of the two types of items, the latter are more analogous to the farmer's wheat.

${ }^{23}$ Griswold at 86.

${ }^{24}$ Griswold at 92. 
Using this distinction to separate the farmer's charitable contribution from the investor's, Dean Griswold supports the Treasury in ruling that the farmer realizes income on the gift. He goes on, however, to propose an alternative way of dealing with the problem. This entails a statutory change and employs his distinction between a gift of an "income" item and a gift of appreciated property. The proposal is to deny the charitable deduction when the gift is of inventory or of other property "the proceeds of which would be fully included in gross income if the property were sold." 25

This distinction between "income" items and other property the crux of Dean Griswold's position - seems to me insufficient to justify either the Treasury ruling or the alternative treatment proposed by Dean Griswold. Dean Griswold himself acknowledges the partial inadequacy of the distinction in the case of property that has given rise to depreciation deductions in past years. ${ }^{26}$ Here the deduction of full market value in the year of gift may result in a double deduction just as in the farmer's case. ${ }^{27}$ The Treasury ruling is silent on the treatment of such property. Dean Griswold would not deny the double deduction here, ${ }^{28}$ though he would deny it to the farmer. Moreover, even nondepreciable property may have given rise to deductions under Section 23 (a) (2), so that the deduction of fair market value at the time of gift might involve a double deduction. ${ }^{29}$ These double deduc-

${ }^{25}$ Ibid.

${ }^{26}$ Griswold at $92 \mathrm{n} .23$.

${ }^{27}$ This would be true if the depreciation deductions exceeded the decline in market value caused by the use of the property. If the excess of market value over adjusted basis were caused simply by appreciation, however, the allowance of a charitable deduction equal to the full market value would involve no duplication of deductions.

${ }^{28}$ Where the property was fully depreciated, however, apparently the charitable deduction would be denied because, in the language of Dean Griswold's proposed statute, "the proceeds of [the property] would be fully included in gross income if the property were sold." The shrewd taxpayer would give such property away while a tiny basis remained, thus obtaining a charitable deduction for its full fair market value. (I am assuming that Dean Griswold's phrase "fully included" simply means that the property's adjusted basis is zero, whether the profit on sale would be ordinary income or capital gain.)

${ }^{20}$ An example would be the deduction of the cost of safekeeping of a noninterest-bearing bond. Since these costs relate solely to holding the bond for appreciation, a subsequent charitable deduction of the full value would involve a duplication. If the bond is interest-bearing, the custodial costs are partially allocable to the production of income over the period of holding, but the rest of these costs would have been deducted and a charitable deduction of the bond's full value would entail a double deduction. 
tions would not be touched by either Dean Griswold's proposal or the Treasury ruling. Finally, property may have a zero basis Dean Griswold's test for denying the charitable deduction although its production gave rise to no deductions either under Section 23 (a) or as part of the cost of goods sold. This category. would include inventions, literary and musical compositions, works of art, and even, in the case of the family farm, some agricultural products. Here there is no danger of a double deduction, yet the Griswold proposal would deny the charitable deduction altogether.

A more fundamental objection to both the Treasury ruling and the Griswold proposal is that their remedies do not fit the disease. Neither takes any account of the extent to which there actually are overlapping deductions. The market value of an agricultural product may reflect heavy deductible expenditures and little appreciation in value, or it may represent only minor expenses with great appreciation. In the former case, a charitable deduction in full would be largely a second deduction of expenses already charged off; in the latter case, only a small part of the charitable deduction would duplicate charged off expenses. Yet the Griswold proposal would deny the charitable deduction entirely in both cases, while the Treasury ruling, in allowing the charitable deduction, would compel it to be offset by the recognition of income. To my mind, the farmer should not be allowed a double deduction, but neither should he be required to recognize the appreciation any more than the security investor.

This brings me to my own solution of the problem: to allow the value of the crop as a charitable deduction without reporting the value as income, but to disallow the expenses of raising the crop. This would prevent the double deduction to which both Dean Griswold and the Treasury properly object, while granting to the farmer the same privilege now enjoyed by the investor of deducting the full value of appreciated property without recognizing the appreciation as income.

While legislation to this end would be desirable, I incline to the. belief that it would not be necessary: the expense of raising a crop that is not sold is simply not an "ordinary and necessary" expense of carrying on a trade or business. ${ }^{30}$ There is a precedent

${ }^{30}$ See Griswold at 85 n.6. See also INT. Rev. Code $\$ 24$ (a) (x) (personal expenses not deductible); U.S. Treas. Reg. III, § 29.23(a)-I (I943) (no double deductions). 
for such a disallowance in the treatment of the cost of raising farm produce consumed by the farmer and his family; such costs are not deductible. ${ }^{31}$ It would of course be necessary to allocate many expenses among the products that are in fact sold and those that are given away; this must now be done for home-consumed produce and, under the Revenue Act of I95I, for an unharvested crop sold with the land. ${ }^{32}$ Once the expenses to be disallowed have been identified, the statute of limitations would rarely interpose a barrier to disallowance, since most of the expenses in question would undoubtedly have arisen in the year of harvest or in the preceding year..$^{33}$

No doubt it will be argued that if the farmer does not raise the crop with the charity in mind, deciding only later to make the contribution, his expenses are "ordinary and necessary expenses" under Section 23 (a) on the facts known when paid or incurred. His subsequent charitable impulse, especially if it bursts out in a later year, ought not - the argument will continue - to result in retroactive disallowance of the expenses. If this objection is valid, it can be met by legislation, though a Treasury regulation along the lines indicated would to my mind be more consistent with the present law than the ruling that was issued.

What is sauce for the goose is sauce for the gander. If the farmer is to be denied a double deduction, the investor should be placed under an equal disability. The problem here is less serious, since ordinarily the investor's expenses under Section 23 (a) (2) would be minor in amount and sometimes incapable of allocation to the donated securities. The owner of depreciable property ought also to be treated harmoniously with the farmer, to the extent that a charitable deduction of fair market value would duplicate his deductions for depreciation in past years. ${ }^{34}$ There

${ }^{31}$ Form I040F, D. 4.

32 INT. REv. CODE $\$ \S 24(f), I_{3}(b)(I)(L), \operatorname{II} 7(j)(3)$.

${ }^{33}$ If the crop basis of accounting is employed, the expenses, no matter when incurred, would not be deducted until the year of disposition of the crop. U.S. Treas. Reg. III, §§ 29.22(a)-7, 29.23(a)-II (I943).

${ }^{34}$ See note 27 supra. As a practical matter, it may be difficult to distinguish between the effects of excessive depreciation deductions and appreciation in value. Presumably this would require a comparison of the value of the donated property with the value of undepreciated property at the time of the gift to determine the proportion of the original cost properly allocable to the preceding period of its use. In the usual case, however, it would seem reasonable to accept the depreciation deductions already allowed as proper and to allow a charitable contribution deduction of the full market value. 
is here an administrative complication, however. If the taxpayer has owned the property for a long period, retroactive disallowance of excessive depreciation deductions would require stale returns to be reopened. Perhaps instead such a taxpayer's charitable deduction should be the value of the property less any previous excessive reductions of its basis. ${ }^{35}$ Then he too would be able to recover his original cost plus appreciation - but no morewithout realizing income thereby.

Finally, Dean Griswold's widget manufacturer: How should a gift of widgets to a charity be taxed? The manufacturer will get a double deduction if he can include the expense as part of his cost of goods sold without taking anything into income and at the same time can deduct their value as a charitable contribution. ${ }^{36}$ Dean Griswold suggests "an adjustment of the inventory," in recognition of the fact that the widgets were not sold, and I would agree. $^{37}$ Then allowing the manufacturer to deduct the fair market value of the widgets as a contribution to charity would give him the same privilege as to unrealized appreciation that is

${ }^{35}$ Restricting the deduction to that part of the property's value in excess of the previous deductions which would otherwise be duplicated would be authorized by U.S. Treas. Reg. III, $\$ 29.23$ (a)-I (I943). In fact, this solution to the bogey of double deductions could be adopted for all contributions, including the farmer's wheat. It would have only these defects, not shared by the solution suggested in the text: the deduction might be split between two years, rather than allocated to the year of gift; and the $15 \%$ limitation of $\S 23(0)$ would be ignored to the extent that the total allowable deduction took the form of a business or depreciation, rather than a charitable contribution, deduction. This latter defect is shared by Dean Griswold's proposed statute.

${ }^{36}$ The double deduction would occur in the year of the gift, no matter when the manufacturing expense was incurred, if inventory is valued at cost. This is because inclusion of the expense in the cost of goods sold would have been offset by the inclusion of the widgets themselves in inventory, leaving the manufacturer's tax liability unaffected by the expense until the widgets are removed from inventory. If the inventory was reduced to a lower market value, however, part of the manufacturing expense would have reduced income in the year of inventory revaluation.

${ }^{37}$ Griswold at 85 n.6. The adjustment would be simple in the case where the goods were manufactured in the year of the contribution, requiring only disallowance of the allocable expenses. If the expense had been incurred in an earlier year, on the other hand, it would be reflected in opening inventory, and the widgets would be removed from closing inventory. To make an adjustment in this case, the cost of the widgets could be credited to Cost of Goods Sold and debited to Gifts to Charity or an equivalent account, thus counterbalancing the reduction of income caused by removing the widgets from the closing inventory. This appears to be current accounting practice, and it avoids the necessity of adjusting the opening inventory. Deducting the fair market value of the widgets as a charitable contribution would then give the manufacturer an allowance for the cost plus the appreciation of the property, but without any double deduction. 
now enjoyed by the investor and that would be enjoyed under my proposal by the farmer.

The other Treasury ruling to which both Dean Griswold and Mr. Miller direct their attention held that a taxpayer realized income when he gave some cattle to his son. ${ }^{38}$ The cattle were raised in the ordinary course of his business, so that the father's expenses had been deducted and his basis was zero. The cattle were worth $\$ I_{500}$ at the time of gift and eight months later were sold by the son for $\$ 2$ I00. The Treasury ruled that the father realized income on the gift in the amount of $\$ I_{500}$ and that the son realized $\$ 600$ of income on selling the animals. The cattleman and his son presumably hoped that the father would have no income on the transaction, that the son's basis would be the same as his father's, under Section II3(a)(2), and that the son's income on sale would be $\$ 2$ roo.

Much could be said for taxing any appreciation in the value of property to its owner when he disposes of it by either inter vivos or testamentary gift. But Congress has chosen another course of action, and the Code now provides by Section $\operatorname{Ir}_{3}(a)(2)$ that the donor does not realize income by an inter vivos gift and that his donee shall take over his donor's basis. ${ }^{39}$

Now, while the Treasury Department ought not to be niggardly in accepting an unpalatable decision by Congress, it is not under any more of a duty than the taxpayer to reduce its revenue to the smallest possible sum. The public interest may be served by challenging the efforts of taxpayers to make a fortress out of this or that detail of the Code. The litigation policy that culminated in Helvering $v$. Clifford, ${ }^{40}$ for example, seems to me not only proper but laudable in its refusal to accept Sections I66 and I67 as the sole line of demarcation between taxing the grantor of a trust and taxing the trustee or beneficiary. But even from this viewpoint, which of course many would condemn as unduly latitudinarian, I am troubled by the ruling in question, since I find no adequate way to differentiate the transaction there con-

${ }^{38}$ I.T. 3932, I948-2 CuM. BuLr. 7. In W. G. Farrier's Estate, I5 T.C. 277 (I950), the Tax Court, without either endorsing or rejecting this ruling, held that it was inapplicable where the donee had not sold the donated cattle.

${ }^{39}$ To be sure, $\S \operatorname{Ir}_{3}(\mathrm{a})(2)$ merely establishes the donee's basis, without explicitly relieving the donor of tax liability for the difference between his basis and the property's value. But this exemption of the donor flows by negative inference: there was surely no intent to tax the same increment to both donor and donee.

${ }^{40} 309$ U.S. 33 I (I940). 
sidered from the generality of transactions subject to Section II3(a) (2).

Is it the Treasury's view that, notwithstanding Section II3(a) (2), a gift constitutes a realization of income (with a correspondingly stepped-up basis for the donee) whenever the donor has had deductions attributable to the donated property? Such a rule would embrace depreciable property as well as inventory property and stock in trade; it might even include securities. There being no question here of a double deduction, there is to my mind even less reason to distinguish among various types of appreciated property than in the case of charitable contributions. Is the ruling limited to property with a zero basis? If so, what in the Horst case - upon which the ruling purports to rest - affords a basis for distinguishing between property with a zero basis and other property?

The tax abuse at which the ruling is directed, I take it, does not grow out of the property's zero basis. The Treasury's complaint is rather: (a) that income is being diverted by the gift from the father to the son; (b) that in the process of transfer the income ultimately reported may be converted from ordinary income (the property not being a capital asset in the hands of the father) to capital gain (if the son does not hold for sale to customers) $;^{41}$ and (c) that the father has had the benefit of business deductions in creating the donated property.

Problem (a) is as old as the income tax, and the gift in question should be subject to the same rules as any other intra-family diversion of income. In a proper case the total income, not just the increment to the date of gift, could be taxed to the father. Such action would be authorized by Commissioner v. Court Holding Co., ${ }^{42}$ for example, when its criteria are met. Imputing the income to the father under that decision would not fly in the teeth of Section Ir3(a) (2), as does the ruling, since instead of mechanical application there would be a consideration of motive, prearrangement and other factors. Or - again under proper circumstances - the Treasury might tax the entire income to the donor

41 The Treasury's view, embodied in this ruling, is that the cattle were not capital assets in the hands of the son because of $\S \operatorname{II} 7(a)(\mathrm{r})(\mathrm{A})$. It does not appear whether this is because the son was himself in the livestock business (apart from this transaction), because this transaction alone was sufficient to characterize the cattle as business property, or because the father's status is in the Treasury's opinion to be visited upon his son.

${ }^{42} 324$ U.S. 33 I (1945). 
under Lucas v. Earl, ${ }^{43}$ upon a showing that it was the result of the father's personal services, or under the Clifford case, upon a showing that the donor's control was not terminated by the transfer. Section II3(a) (2) makes it quite clear, however, that prospective income (in the form of unrealized appreciation on property) can be reallocated by some gifts; the ruling either seeks to deny this obvious fact of life or else rests upon a carefully concealed distinction between the gifts to which it was intended to apply and those that remain subject to Section $\mathrm{xI}_{3}(\mathrm{a})(2)$.

The conversion of a noncapital asset into a capital asset by transferring it from the professional father to the amateur son is unquestionably a problem of importance, though of course the repeated use of the scheme will bring the son into the professional class and thus defeat its own purpose. This may have been the abuse at which the ruling is aimed, ${ }^{44}$ though it does not purport to be so limited, and there is nothing in the Horst case - on which the ruling is built - to indicate that as a general rule income is to be attributed to the donor when to attribute it to the donee would change its character. It should be noted that farmers and cattlemen are not the only ones who might seek to avail themselves of this loophole; it might be exploited by any taxpayer holding inventory property or stock in trade, or even real estate. ${ }^{45}$ In any event, the transmutation is important only as it reduces the family total tax burden, and it is merely another facetthough a flashy one - of the general problem of reallocating income within the family in order to lessen the impact of the graduated income tax. ${ }^{46}$ The Treasury can hardly deny that Sec-

43 28I U.S. III (I930).

${ }^{44}$ In W. G. Farrier's Estate, I5 T.C. 277 (I950), the Commissioner sought to $\operatorname{tax}$ the donor of cattle on their value at the time of gift. The Commissioner's deficiency was limited to part of the donated cattle, possibly to those whose sale by the donor would have resulted in the realization of ordinary income (rather than capital gain). The Tax Court held no income was realized by the donor. See note 38 supra.

45 If the donor held real property used in his trade or business, a sale by him would have resulted in ordinary income, INT. REv. CoDE § II 7 (a) (I)(B); Fackler v. Commissioner, I33 F.2d 509 (6th Cir. I943), unless the peculiar conditions of $\S$ II7(j) are met. The donee, if he sold immediately, would be sure of capital gain treatment.

${ }^{46}$ Specific statutory provisions were thought necessary to combat similar transmutations in two other areas. Section $I I \eta(a)(I)(C)$ provides that a copyright or similar property shall not be a capital asset when held by its creator or by his donee. Donees were placed on a par with their donors "to avoid a loophole." Sex. Rep. No. 2375, 8Ist Cong., 2d Sess. 44 (I950). The Revenue Act of I95I 
tion $\operatorname{Ir}_{3}(a)(2)$ is applicable by and large to gifts of appreciated securities, despite the fact that the donee's tax rate on the income is lower than the donor's. Whether the tax saving is achieved by taking advantage of the son's lower tax bracket (as in the case of securities) or of his amateur status (as in the case of livestock) seems to me a mere matter of detail. If the Court Holding Co., Clifford, or Lucas cases are applicable, the income is taxed to the father as though he had not disposed of it; if, on the other hand, the conditions are not ripe for taxing the father on these theories, the transaction should be reckoned as an effective transfer and the son taxed in his own right.

Finally, as stated above, the Treasury in issuing its ruling may have been aggrieved by the cattleman's business deductions. Much can be said for disallowing the deductions on the theory that they are permissible only when they contribute to the earning of income. ${ }^{47}$ If the taxpayer forswears the income itself, he should not be able to claim that the expenses were "ordinary and necessary" in carrying on his trade or business. I do not find anything in the Horst case or elsewhere, however, to support the Treasury's view, if it is the Treasury's view, that because of the deductions the gift is a realization of income. Section $\operatorname{II}_{3}(a)(2)$ contemplates that the donee is the donor's surrogate and takes over the donor's basis. The donee's subsequent sale requires him to recognize the same amount of income that the donor would have recognized if he had held the property and sold it himself. There is here no double deduction, as might occur in the case of a charitable contribution of the same property.

amended $\S I I \eta(m)$ to prevent the conversion of stock in trade and inventory into capital assets by the use of a "collapsible corporation." In recommending this legislation, the House Committee on Ways and Means said that no inferences were to be drawn as to the validity of the scheme in previous years. H.R. RER. No. 586, 82d Cong., Ist Sess. 26 (I95I).

47 If disallowed, the expenses would then constitute a basis which would be transferred to the son under $\S \operatorname{Ir}_{3}(a)(2)$. 